\title{
Workshop peningkatan kemampuan guru menulis rencana penelitian tindakan kelas di Kecamatan Minas Kabupaten Siak
}

\author{
Yenita Roza* dan Sehatta Saragih \\ Universitas Riau \\ *yenita.roza@lecturer.unri.ac.id
}

\begin{abstract}
Abstrak. Penelitian Tindakan Kelas merupakan salah satu bentuk penelitian yang direkomendasikan untuk dilakukan oleh guru dalam pengembangan kapasitas sebagai seorang guru professional. Melalui penelitian ini guru sekaligus memperbaiki kualitas pembelajaran yang dilakukan di kelas, sehingga ini dijadikan salah satu syarat dalam pengusulan kenaikan pangkat guru. Dari wawancara dan pengamatan di Kecamatan Minas Kabupaten Siak ditemukan banyak guru yang terkendala dalam pengusulan naik pangkat karena kemampuan mereka dalam melakukan penelitian tindakan kelas rendah. Pengabdian yang dilakukan bertujuan untuk mendampingi guru dalam menulis rencana Penelitian Tindakan Kelas (PTK) sehingga mereka siap untuk melakukan PTK. Masyarakat sasaran kegiatan adalah 30 orang guru SMP dengan masa kerja yang bervasiasi mulai dari 4-15 tahun. Kegiatan dilakukan melalui workshop yang dilaksanakan dalam lima tahapan yaitu pembekalan pengetahuan tentang PTK, Pendampingan penulisan Rencana PTK, Diskusi Rencana PTK, Perbaikan Rencana PTK dan Seminar Usulan PTK. Hasil pengabdian memperlihatkan bahwa kegiatan workshop memberikan dampak positif terhadap kemampuan peserta dalam menyusun rencana PTK. Rataan capaian peserta dalam skala 4 adalah 2.53 dengan kategori baik.
\end{abstract}

Kata kunci: guru profesional; PTK; workshop guru

Abstract. Classroom Action Research (CAR) is one form of research that is recommended to be carried out by teachers in developing capacity as a professional teacher. Through this research the teacher at the same time improves the quality of learning carried out in the classroom, so that this is used as one of the conditions in proposing teacher promotion. From interviews and observations in Minas Subdistrict, Siak Regency, there were many teachers who were constrained for promotion because of their ability to conduct class action research is low. The program done aims to assist the teacher in writing Class Action Research (CAR) plans so that they are ready to do the research. The target community of the activity is 30 junior high school teachers with varied working experience ranging from 4-15 years. The activities were carried out through workshops conducted in five stages, namely debriefing about action research, mentoring of research plan writing, research plan discussion, revision of research plans and presenting of research plan. The results of the service showed that the workshop activities had a positive impact on the ability of participants to develop CAR plans. The average achievement of participants in scale 4 is 2.53 in the good category.

Keywords: classroom action research; professional teacher; teacher workshop

\author{
To cite this article: Roza, Y., \& S. Saragih. 2019. Workshop Peningkatan Kemampuan Guru Menulis Rencana \\ Penelitian Tindakan Kelas di Kecamatan Minas Kabupaten Siak. Unri Conference Series: Community Engagement \\ 1: 394-400 https://doi.org/10.31258/unricsce.1.394-400 \\ (C) 2019 Authors \\ Peer-review under responsibility of the organizing committee of Seminar Nasional Pemberdayaan Masyarakat 2019
}




\section{PENDAHULUAN}

Peningkatan profesionalisme guru sampai saat ini terus dilakukan pemerintah dengan berbagai cara dan strategi, seperti melaksanakan workshop, sosialisasi dan mengaktifkan Kelompok Kerja Guru (KKG) dan Musyawarah Guru Mata Pelajaran (MGMP). Salah satu kegiatan peningkatan prosesonalisme guru dilakukan melalui tugas pokoknya seperti kewajiban mengembangkan Penelitian Tindakan Kelas (PTK). Peningkatan profesionalisme guru melalui kegiatan pengembangan PTK diimplemetasi dalam prasyarat kenaikan pangkat guru khususnya untuk golongan III. Kewajiban membuat PTK sebagai prasyarat pengusulan kenaikan pangkat, berdampak pada kelancaran kenaikan pangkat guru. Dari hasil wawancara dengan koordinator Pendidikan dan Kebudayaan Kecamatan Minas didapatkan informasi tidak kurang dari 40 orang guru untuk semua jenjang pendidikan (SD, SMP, dan SMA) terkendala naik pangkat karena tidak dapat memenuhi prasyarat tersebut. Sebagai bagian dari kemampuan professional, maka seharus guru tidak merasa kegiatan PTK sebuah hambatan atau beban dalam kenaikan pangkatnya sebaliknya kegiatan PTK seharusnya merupakan suatu penunjang kegiatan profesionalisme guru yang sifatnya berkelanjutan. Melalui Penelitian Tindakan Kelas guru sebagai pengelola pembelajaran diharapkan dapat meningkatkan proses pembelajaran yang akan berdampak pada peningkatan hasil belajar siswa.

Faktor penyebab tersebut merupakan sebuah rangkaian terstruktur dalam mengembangkan Penelitian Tindakan Kelas. Menindaklanjuti kondisi diatas maka dalam membantu guru harus diawali dengan membekali guru pengetahuan yang terkait konsep Penelitian Tindakan Kelas, mengembangkan ide-ide pembelajaran yang tepat diangkat sebagai topik penelitian dan meningkatkan kemampuan guru dalam mengembangkan usulan penelitian. Melalui tahapan ini diharapkan guru punya kemampuan untuk mengimplementasikannya dalam proses pembelajaran.

Secara konseptual rangkaian kegiatan pengembangan Penelitian Tindakan Kelas dapat dibagi 3 tahap, yaitu Mengembangkan ide penelitian dalam bentuk usulan Penelitian Tindakan Kelas, Melaksanakan implementasi Penelitian Tindakan Kelas dalam proses pembelajran, Membuat laporan Penelitian Tindakan Kelas (Kunandar, 2011).

Penelitian Tindakan Kelas (Suharsimi, 2010) merupakan suatu pencermatan terhadap kegiatan berupa sebuah tindakan, yang sengaja dimunculkan dan terjadi dalam sebuah kelas bersama. Secara garis besar penelitian tindakan kelas dilaksanakan melalui empat tahap yaitu (1) perencanaan; (2) pelaksanaan; (3) pengamatan; dan (4) refleksi. Menurut (Kunandar, 2011), Penelitian Tindakan Kelas adalah "penelitian yang dilakukan oleh guru di dalam kelasnya sendiri melalui refleksi diri, dengan tujuan untuk memperbaiki kinerjanya sebagai guru, sehingga hasil belajar siswa meningkat".

Dari pendapat di atas diperlihatkan bahwa penelitian tindakan kelas adalah penelitian yang dilakukan di dalam kelas dengan tujuan untuk memperbaiki proses dan meningkatkan hasil belajar siswa. Namun demikian, sampai saat ini kenyataan menunjukkan bahwa kegiatan Penelitian Tindakan Kelas belum menjadi bagian dari kegiatan rutinitas guru. Banyak faktor yang menyebabkan hal ini, salah satunya adalah minimnya pengetahuan dan terbatasnya kemampuan guru dalam mengembangkan sebuah Penelitian Tindakan Kelas. Sehubungan dengan itu, maka perlu upaya berbagai pihak dalam membantu guru agar masyarakat sasaran memiliki pengetahuan, kemampuan dan keterampilan mengembangkan Penelitian Tindakan Kelas.

Menindaklanjuti permasalahan yang dialami guru-guru SMP di Kec. Minas dalam hal mengembangkan PTK maka tim dosen Program Magister Pendidikan Matematika memfasilitasi guru-guru SLTP di-Kec Minas Kabupaten Siak untuk mengembangkan ide penelitian dalam bentuk usulan Penelitian Tindakan Kelas melalui workshop. Sasaran kegiatan ini adalah kelompok Musyawarah Guru Mata Pelajaran (MGMP) Kecamatan Minas Kabupaten Siak Propinsi Riau. Dalam kegiatan ini diberikan kesempatan kepada semua guru-guru dari berbagai bidang studi yang kenaikan pangkatnya terkendala karena tidak memiliki Penelitian Tindakan Kelas. Kegiatan ini bertujuan untuk meningkatkan pengetahuan dan wawasan, ketrampilan menyusun rencana dan melaksanakan PTK bagi guru SMP Kecamatan Minas.

Sebagaimana yang dikemukakan sebelumnya bahwa masyarakat sasaran kegiatan ini adalah guru SMP yang berada dilingkungan Kantor Koordinator Wilayah Pendidikan dan Kebudayaan Kec. Minas Kab. Siak. Berdasarkan absensi kegiatan, diperoleh informasi bahwa jumlah guru yang menjadi masyarakat sasaran kegiatan pengabdian ini sebanyak 30 orang. Secara umum masyarakat sasaran kegiatan ini berlatar belakang pendidikan sarjana Pendidikan, sarnaja ilmu murni dan beberapa diantaranya magister pendidikan.

Berdasarkan pengalaman mengajar, terdapat 6 orang masyarakat sasaran dengan pengalaman kerja lebih dari 15 tahun, 12 orang dengan pengalaman antara 5 sampai dengan 10 dan selebihnya dibawah 5 tahun. 
Selanjutnya dari 30 masyarakat sasaran hanya 4 orang yang pernah mengikuti kegiatan serupa melalui kegiatan MGMP.

Terkait dengan pengembangan kemampuan guru dalam Penelitian Tindakan Kelas sebagai bagian dari kemampuan profesional guru, dari 30 guru sebagai masyarakat sasaran diperoleh fakta bahwa hanya dua orang peserta yang pernah melakukan PTK secara mandiri, 5 orang secara kolaboratif dan selebihnya belum pernah. Dengan demikian secara umum masyarakat sasaran belum memiliki pengalaman yang cukup dalam mengembangkan Penelitian Tindakan Kelas.

Dari aspek yang dijadikan tolok ukur keberhasilan program, secara umum masyarakat sasaran mengalami kesulitan dalam mengembangkan ide awal penelitian yakni mengungkapkan permasalahan yang mereka temuai dalam proses pembelajaran dan merancang solusi yang cocok dan tepat. Ketidakmampuan peserta secara umum dalam hal ini terletak pada mengidentifikasi permasalahan yang dihadapi dalam proses pembelajaran yang didasarkan pada hasil refleksi yang dilakukan. Disamping itu, dalam mengembangkan solusi yang dipilihkan banyak masyarakat sasaran yang kurang mampu karena minimnya pengetahuan dan kemampuan mereka terkait model-model pembelajaran.

Selanjutnya dalam kajian teori beberapa kesulitan peserta terletak pada: (1) mengembangkan hubungan antara solusi yang dipilih dengan masalah yang diangkat dalam penelitian; (2) Mengembangkan langkahlangkah pembelajaran berdasarkan model, strategi atau metode pembelajaran yang dipilihkan. Namun demikian secara umum peserta masyarakat sasaran mampu mengembangkan kajian teori sesuai dengan variabel penelitiannya. Dalam metode penelitian secara umum tahapan penelitian tindakan kelas yang dikembangkan telah sejalan dengan yang ditetapkan. Kelemahan peserta dalam aspek ini adalah; (1) mengembangkan perangkat pembelajaran berdasarkan langkah-langkah pembelajaran yang ditetapkan dalam kajian teori; (2). mengembangkan instrument pengumpul data terutama yang terkait dengan lembar observasi.

\section{Potensi Pengembangan Masyarakat Sasaran}

Sebagaimana yang dikemukakan sebelumnya bahwa pengembangan penelitian tindakan kelas merupakan salah satu kemampuan profesionalisme guru maka dapat dikatakan bahwa masyarakat sasaran sangat potensi dalam melaksanakan sebuah Penelitian Tindakan Kelas. Selanjutnya memperhatikan latarbelakang pendidikan masyarakat sasaran dan pengalaman bekerja sebagai guru dan diklat yang sudah diikuti serta antusias mereka selama mengikuti kegiatan ini maka dapat dikatakan bahwa masyarakat sasaran memiliki potensi untuk mengembangkan Penelitian Tindakan Kelas.

Disamping itu, adanya wadah kelompok guru mata pelajaran untuk berkumpul saling berbagi pengalaman yakni MGMP dapat dijadikan sebagai wahana pengembangan kemampuan peserta masyarakat sasaran dalam mengembangkan Penelitian Tindakan Kelas. Wadah MGMP merupakan tempat guru bekerja bersama dalam meningkatkan profesionalismenya maka masyarakat sasaran dapat berperan aktif didalamnya. Dengan peran aktif ini akan meningkatkan kemampuan dan pengalaman peserta masyarakat sasaran dalam mengembangkan Penelitian Tindakan Kelas. Letak geografis sekolah masyarakat sasaran yang ditidak berjauhan memungkinkan mereka membentuk kelompok-kelompok teman sejawat dalam mengembangkan Penelitian Tindakan Kelas.

\section{MASALAH}

Dari data awal yang dikumpulkan melalui wawancara, permasalahan yang dihadapi oleh guru di Kecamatan Minas Kabupaten Siak adalah:

1. Terbatasnya kemampuan guru mengembangkan ide awal penelitian yang dapat diangkat sebagai topik Penelitian Tindakan Kelas

2. Guru tidak memiliki pengalaman dan keterampilan dalam mengembangkan rencana kegiatan Penelitian Tindakan Kelas dalam bentuk usulan penelitian

3. Guru tidak memiliki kemampuan mengimplementasikan Penelitian Tindakan Kelas dalam proses pembelajaran

4. Guru tidak memiliki pengetahuan dan kemampuan membuat laporan kegiatan Penelitian Tindakan Kelas.

Faktor penyebab tersebut meruapakan sebuah rangkaian terstruktur dalam mengembangkan Penelitian Tindakan Kelas. Menindaklanjuti kondisi diatas maka dalam membantu guru harus diawali dengan membekali guru pengetahuan yang terkait konsep Penelitian Tindakan Kelas, mengembangkan ide-ide pembelajaran yang tepat diangkat sebagai topik penelitian dan meningkatkan kemampuan guru dalam mengembangkan usulan penelitian. Melalui tahapan ini diharapkan guru punya kemampuan untuk mengimplementasikannya dalam proses pembelajaran. 


\section{METODE}

Sebagaimana dikemukakan sebelumya bahwa tujuan utama kegiatan ini adalah menghasilkan usulan kegiatan Penelitian Tindakan Kelas bagi peserta workshop. Sehubungan dengan itu, perlu dirancang tahapan kegiatan agar berjalan dengan baik dan mencapai tujuan yang ditetapkan. Adapun tahapan pelaksanaannya kegiatan workshop ini adalah sebagai berikut:

\section{Tahap Persiapan}

Pada tahap persiapan dilakukan koordinasi dengan LPPM Universitas Riau dan Koordinator Wilayah Pendidikan dan Kebudayaan Kecamatan Minas dan Dinas Pendidikan Kabupaten Siak dalam rangka sosialisasi kegiatan pengabdian. Koordinasi juga dilakukan dengan ketua MGMP Kecamatan Minas dalam rangka konsolidasi terkait dengan guru yang diundang, waktu pelaksanaan, mempersiapkan tempat dan sarana penunjang kegiatan. Berdasarkan hasil diskusi diatas maka tim pengabdian menyiapkan bahan sesuai dengan kebutuhan masyarakat sasaran pengabdian.

\section{Tahap Pelaksanaan}

Pelaksanaan kegiatan workshop dibagi atas:

1. Tahap Pembekalan Pengetahuan dan Wawasan Penelitian Tindakan Kelas

Dalam tahap ini, kegiatan workshop adalah membekali peserta masyarakat sasaran yakni guru-guru tentang Penelitian Tindakan Kelas secara teoris. Topik-topik yang disajikan dalam pembekalan ini adalah pengertian, hakekat dan konsep/prinsip Penelitian Tindakan Kelas, arti penting Penelitian Tindakan Kelas bagi guru, dan Rambu-rambu mengembangkan usulan Penelitian Tindakan Kelas.

2. Latihan Pengembangan Usulan Penelitian Tindakan Kelas

Setelah masyarakat sasaran mendapat pengetahuan dan wawasan tentang Penelitian Tindakan kelas dan rambu-rambu pengembangan usulan Penelitian Tindakan Kelas, maka peserta didampingi mengembangkan draft usulan Penelitian Tindakan Kelas. Pada tahap ini, TIM memfasilitasi peserta dalam hal: (1) mengembangkan ide-ide atau permasalahan yang ditemui dalam proses pembelajaran yang dapat dijadikan topic Penelitian Tindakan Kelas; (2) memilih model/metode atau strategi pembelajaran yang dijadikan solusi terhadap permasalahan yang diangkat; (3) mengembangkan jenis instrument penelitian yang dibutuhkan.

3. Diskusi Usulan Penelitian Tindakan Kelas

Dalam tahap ini kegiatan workshop adalah berbagi pendapat atau ide antara peserta dengan TIM terkait draft usulan Penelitian Tindakan Kelas yang dibuat peserta. Sehubungan dengan itu, maka semua peserta diminta mempresentasi kan draf usulan Penelitian Tindakan Kelas yang dibuat. Kepada semua peserta diminta memberikan masukan atau saran terkait dengan isi usulan Penelitian Tindakan Kelas yang dipresentasikan dalam rangka meningkatkan dan memperkuat pemahaman peserta tentang Penelitian Tindakan Kelas. Disamping itu, melalui diskusi ini diharapkan peserta akan lebih memahami kekurangkan-kekurangan usulan yang dibuat dan memperbaikinya sesuai dengan saran yang diberikan.

4. Perbaikan Usulan Penelitian Tindakan Kelas

Pada tahap ini, berdasarkan masukan dalam tahap diskusi peserta diminta memperbaiki draft usulan penelitiannya. Dari kegiatan ini diharapkan usulan yang dibuat peserta lebih baik dan sesuai dengan format yang diberikan saat pembekalan.

5. Seminar Usulan Penelitian Tindakan Kelas

Seminar usulan penelitian ini bertujuan untuk memantapkan pemahaman peserta terkait dengan usulan yang mereka buat. Berdasarkan usulan penelitian yang dikembangkan, TIM memberikan koreksi dan mengarahkan perbaikan terkait dengan kelemahan atau kekurang agar lebih terarah. Tujuan dari kegiatan seminar ini adalah peserta diharapkan mampu mengkomunikasikan ide-ide penelitiannya dengan baik, dan memahami kelemahaman-kelemahan usulan yang mereka buat dan melakukan perbaikannya, serta memahami tahapan implementasi Penelitian Tindakan Kelas yang mereka rancang. Memiliki kemampuan dan keterampilan dalam mengembangkan jenis instrument penelitian yang dibutuhkan.

\section{PEMBAHASAN}

\section{Pelaksanaan Kegiatan}

Sesuai dengan perencanaan maka kegiatan workshop dilakukan dengan memberikan materi tentang PTK, mendampingi guru menulis usulan PTK, Guru mempresentasikan usulan yang sudah ditulis dan revisi usulan 
yang sudah dibahas. Pada kegiatan ini tim juga melibatkan mahasiswa sebagai pendamping narasumber dengan tujuan memberikan pengalaman kepada mereka dalam mendampingi guru. Berikut disajikan dokumentasi beberapa bagian dari kegiatan.
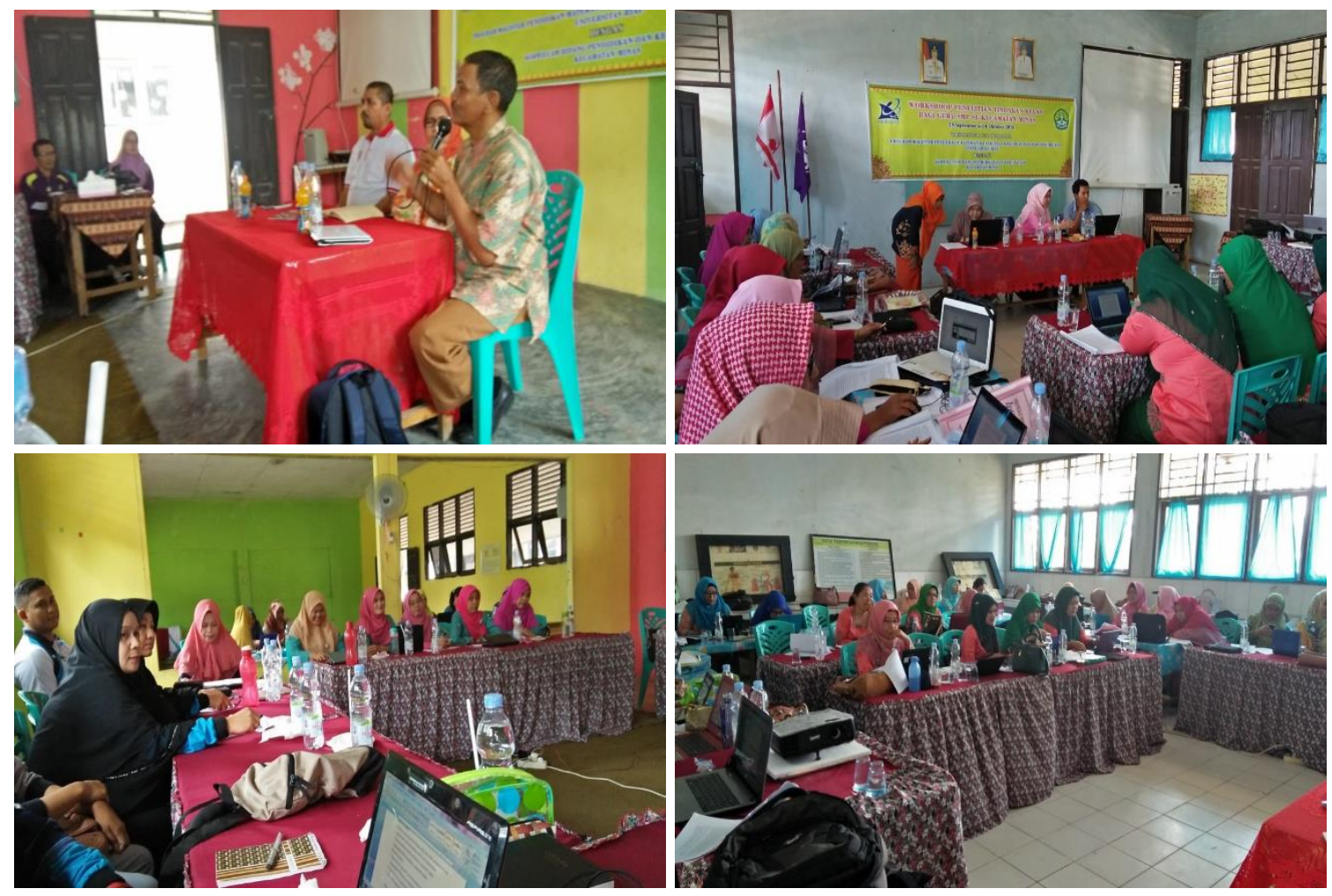

Gambar 1. Foto kegiatan pembukaan, penyajian materi dan pendampingan

Dari pelaksanaan kegiatan ditemukan fakta bahwa dalam rangka memperkuat pengalaman masyarakat sasaran dalam mengembangkan usulan dan melaksanakan Penelitian Tindakan Kelas, sebaiknya masyarakat sasaran diberdayakan dalam mendampingi teman sejawat pada sekolah yang sama. Kegiatan pendampingan sejawat ini disamping sebagai tempat bertukar informasi juga memudahkan mereka untuk meminta bantuan jika diperlukan dan yang utama adalah pengalaman mereka dalam melaksanakan Penelitian Tindakan Kelas.

\section{Tingkat Ketercapaian Program}

Berdasarkan tujuan program kegiatan ini yakni meningkatkan kemampuan masyarakat sasaran dalam mengembangkan usulan penelitian tindakan kelas, sehubungan dengan itu maka berikut ini akan dideskripsikan tingkat ketercapaian program berdasarkan kemampuan peserta dan aspek pengukuran usulan penelitian yang dikembangkan.

1. Tingkat ketercapaian program berdasarkan kemampuan peserta masyarakat sasaran. Berdasarkan skor penilaian terhadap usulan penelitian masyarakat sasaran maka diperoleh fakta bahwa secara umum rataan hasil penilaian usulan penelitian Tindakan Kelas peserta adalah 2,53 dengan kategori Baik.

2. Tingkat ketercapaian program berdasarkan aspek penilaian usulan penelitian. Berdasarkan skor penilaian terhadap setiap aspek penilaian usulan penelitian tindakan kelas yang dikembangkan, diperoleh kemampuan masyarakat sasaran dalam mengembangkan usulan penelitian tindakan kelas seperti yang dimuat dalam Tabel 1.

Berdasarkan data pengukuran kemampuan masyarakat sasaran, menunjukkan bahwa kegiatan pendampingan pengembangan usulan Penelitian Tindakan Kelas memberikan dampak positif terhadap kemampuan peserta dalam mengembangkan perencanaan kegiatan PTK. Jika dicermati lebih jauh penguasaan masyarakat sasaran terhadap aspek-aspek yang dinilai dalam mengembangkan usulan PTK, dapat dikatakan belum optimal. Hal ini mengingat bahwa rataan hasil penilaian pada setiap aspek pengukuran usulan PTK yang ditetapkan secara umum masih berada pada kategori baik. Sehubungan dengan itu, maka perlu upaya pendampingan lebih lanjut terkait dengan usulan penelitian yang disusun oleh masyarakat sasaran agar mereka lebih menguasai, memahami, dan terampil dalam mengimplementasikan usulan yang dikembangkan menjadi sebuah penelitian. 
Tabel 1. Kemampuan Peserta Berdasarka Aspek Pengukuran

\begin{tabular}{lcc}
\hline \multicolumn{1}{c}{ Aspek Penilaian } & Rataan & Kategori \\
\hline Pendahuluan & 2,37 & $\mathrm{~B}$ \\
Rumusan Masalah & 2,6 & $\mathrm{~B}$ \\
Tujuan Penelitian & 3,43 & $\mathrm{SB}$ \\
Manfaat Penelitian & 3,36 & $\mathrm{SB}$ \\
Landasan Teoritis & 1,95 & $\mathrm{~KB}$ \\
Metode Penelitian & 2,6 & $\mathrm{~B}$ \\
Daftar Pustaka & 2,5 & $\mathrm{~B}$ \\
Penyajian Proposal & 2,7 & $\mathrm{~B}$ \\
\hline
\end{tabular}

Disamping factor pendukung kesuksesan pelaksanaan kegiatan pedampingan pengembangan usulan PTK untuk guru SMP se-Kec. Minas, juga terdapat beberapa kendala diantaranya adalah: (1) beberapa masyarakat sasaran belum pernah mengembangan Penelitiam Tindakan Kelas selama menjadi guru, terdapat masyarakat sasaran yang berlatar belakang pendidikannya bukan ilmu murni sehingga mereka kesulitan untuk mengembangkan ide-ide pembelajaran menjadi topic kajian penelitian; (2) terbatasnya pengetahuan dan wawasan masyarakat sasaran terkait model/strategi atau metode pembelajaran sehingga menyulitkan mereka mengembangkan solusi perbaikan proses pembelajaran berdasarkan masalah yang diangkat; (3) walaupun megembangan RPP merupakan salah satu tugas pokok guru, namun dalam mengembangkan instrument penelitian yang terkait dengan RPP masyarakat sasaran sangat merasa kesulitan.

Jika kita perhatikan capai kemampuan masyarakat sasaran dalam mengembangkan workshop ini maka dapat dikatakan bahwa pendampingan kegiatan pengembangan usulan Penelitian Tindakan Kelas yang dilaksanakan memberikan dampak terhadap: (1) penguasaan dan wawasan guru SMP Kec. Minas secara konseptual tentang Penelitian Tindakan Kelas; (2) Keterampilan peserta dalam mengembangkan usulan Penelitian Tindakan Kelas; dan (3) mengkomunikasikan ide-ide terkait dengan masalah yang dihadapi dalam proses pembelajaran dan upaya solusi yang dipilihkan serta mengembangkannya dalam sebuah usulan penelitian.

Kegiatan pendampingan pengembangan usulan PTK yang diikuti oleh berbagai bidang studi dan latarbelakang yang bukan guru adalah bentuk perwujudan penerapan tekhnologi tepat guna hasil-hasil kegiatan pengabdian. Terdapat 7 guru dari 30 peserta yang bukan berlatak belakang pendidikan sehingga mereka baru pertama sekali mengenal Penelitian Tindakan Kelas. Berdasarkan pantau TIM pengabdi, kegiatan pendampingan yang dilaksanakan berkontribusi terhadap peningkatan kemampuan guru, khususnya masyarakat sasaran yang bukan berlatar belakang pendidikan. Hal ini terlihat dari diskusi-diskusi dan seminar yanag dilakukan, masyarakat sasaran yang bukan berlatar belakang pendidikan telah mampu mengembangkan dan mengkomunikasikan ide-ide mereka yang tepat dan cocock diangkat sebagai topic sebuah PTK.

\section{KESIMPULAN}

Berdasarkan pada hasil-hasil kegiatan pengabdian ini, maka maka dapat disimpulkan bahwa Kegiatan workshop dalam bentuk pendampingan pengembangan usulan Penelitian Tindakan Kelas bagi guru SMP dilingkungan Kantor Koordintaor Wilayah Pendidikan dan Kebudayaan Kec Minas pada tahun 2018 terlaksana dengan baik dan memberikan dampak positif terhadap kemampuan guru dalam menulis usulan PTK. Pada kegiatan ini tim pengabdian tidak mendampingi guru sampai dengan pelaksanaan dalam kelas sehingga dipandang perlu adanya kegiatan lanjutan untuk membantu guru melaksanakan rencana PTK yang sudah disusun.

\section{UCAPAN TERIMA KASIH}

Ucapan terimakasih kami kepada Universitas Riau yang telah membiayai kegiatan ini melalui dana Hibah akreditasi dengan tema pengabdian dosen melibatkan mahasiswa. Terima kasih juga kepada koordinator Wilayah Pendidikan dan Kebudayaan Kecamatan Minas, ketua MGMP Kec. Minas yang memfasilitasi kegiatan ini. 


\section{DAFTAR PUSTAKA}

Alawiyah, F. 2014. Kesiapan Guru Dalam Implementasi K13. Jurnal Info singkat Kesejahteraan Sosial 5(15)

Kunandar. 2011. Langkah Mudah Penelitian Tindakan Kelas Sebagai Pengembangan Profesi Guru. Jakarta: Rajawali Pres.

Maisyaroh, dkk. 2014. Problematika Implementasi Kurikulum 2013 Bagi Guru Mata Pelajaran IPS MTs. Jurnal Penelitian Pendidikan 2(44).

Peraturan Menteri Pendidikan Nasional Republik Indonesia Nomor 65 Tahun 2013 tentang Standar Proses Pendidikan Dasar dan Menengah.

Peraturan Menteri Pendidikan Nasional Republik Indonesia Nomor 67 Tahun 2013 tentang Standar Proses Pendidikan Dasar dan Menengah.

Saragih, S. 2014. Pengembangan Media Pembelajaran Matematika SD Marginal Lingkungan Kebun Sawit, Laporan Penelitian FKIP UNRI Tidak diterbitkan.

Saragih, S. 2015. Pengembangan Media Pembelajaran Matematika SMP Topik Geometri Berbasis Kontekstual, FKIP UNRI Tidak diterbitkan.

Suharsimi, A. 2010. Prosedur Penelitian: Suatu Pendekatan Praktik (Edisi Revisi). Jakarta: Rineka Cipta. 